\title{
Diabetes mellitus patients' fasting blood sugar levels and quality of life following brief pharmacist counseling with reminders and motivational messages
}

\author{
Okta Muthia Sari ${ }^{1 *}$, Ginanjar Zukhruf Saputri², Akrom $^{2}$
}

\author{
${ }^{1}$ Department of Pharmacy, Faculty of Math and Science, University of Lambung Mangkurat, Banjarbaru, South \\ Kalimantan, Indonesia \\ ${ }^{2}$ Faculty of Pharmacy, Ahmad Dahlan University, Yogyakarta, Indonesia
}

Received: 01 November 2021

Accepted: 24 November 2021

*Correspondence:

Okta Muthia Sari,

Email: okta.sari@ulm.ac.id

Copyright: (C) the author(s), publisher and licensee Medip Academy. This is an open-access article distributed under the terms of the Creative Commons Attribution Non-Commercial License, which permits unrestricted non-commercial use, distribution, and reproduction in any medium, provided the original work is properly cited.

\begin{abstract}
Background: For chronic disease patients, pharmacist counselling with motivating reminder messages has been developed throughout time to promote the success of patient treatment. Diabetes mellitus is a long-term condition. Blood sugar control and an improved quality of life are therapeutic goals in the treatment of diabetes mellitus. The objective of this study was to determine whether changes in fasting blood sugar and quality of life occurred in individuals with diabetes mellitus who received pharmacist counselling coupled by motivating reminder messages.

Methods: This quasi-experimental study used a pre-test-post-test design with control and intervention groups. Data on patients with type 2 diabetes were obtained prospectively at Jetis 1 primary health care in Bantul, Yogyakarta, Indonesia. Seventy-two respondents who met the inclusion criteria were separated into two groups: the control group (36 participants) and the intervention group (36 participants). The patients' quality of life was assessed using the 36-item Short Form (SF-36) questionnaire.

Results: Following pharmacist counselling coupled by motivating reminder messages, patients' mean fasting blood sugar reduced significantly $(\Delta 34.85 \pm 63.36)$, while their mean quality of life score increased considerably $(\Delta$ $13.73 \pm 9.22)$.

Conclusions: Pharmacist counselling combined with motivating reminder messages can help patients with type 2 diabetes lower their fasting blood sugar and enhance their quality of life. The provision of pharmacist counselling followed by brief reminders and motivational messages may be considered to improve type 2 diabetes patient management.
\end{abstract}

Keywords: Blood sugar level, Counselling, Diabetes, Short messages, Quality of life

\section{INTRODUCTION}

Globally, diabetes mellitus affected 463 million people in 2019 (10.7 million people are Indonesians) and is expected to reach 700 million by 2045 . Diabetes mellitus was responsible for 4.2 million fatalities worldwide in $2019 .{ }^{1}$ According to the World Health Organization, diabetes mellitus is managed by lifestyle changes and medication. ${ }^{2}$
Diabetes mellitus treatment is not only about controlling the patient's blood glucose level, but also about preventing or inhibiting disease consequences and optimizing the patient's quality of life. ${ }^{3}$ Numerous studies have demonstrated that the quality of life improves with age. Patients with diabetes mellitus scored poorly in the domains of physical, social, and bodily discomfort, as well 
as in the domains of physical function, emotional state, mental health, and overall health. ${ }^{4-6}$

Diabetes mellitus patients must receive education and counselling regarding treatment and lifestyle adjustment in order to reach the anticipated therapeutic aims. ${ }^{7,8}$ Research has demonstrated that pharmacist counselling improves blood sugar control and overall quality of life in individuals with diabetes mellitus. ${ }^{9-13}$

Pharmacy brief counselling is a newly created counselling technique. The advantages of brief counselling are that it saves time and is more practical because the patient's situation has been assessed. ${ }^{14}$ The effect of brief pharmacist counselling on outpatients with hypertension, diabetes mellitus with hypertension, and chronic obstructive pulmonary disease, has been evaluated. ${ }^{15-18}$

Counselling combined with the delivery of brief messages has been shown to have a beneficial effect on people with diabetes mellitus. ${ }^{19}$ Brief reminder messages can help increase medication adherence, resulting in considerable reductions in fasting blood sugar levels. ${ }^{20}$ Over time, pharmacist counselling with brief motivational reminders has been developed for diabetes patients. ${ }^{18,21}$

Research has indicated that providing pharmacist counselling in conjunction with brief motivational reminder messages helps enhance diabetic patients' knowledge, medication adherence, blood sugar management, and HbA1c control. ${ }^{18,21}$ However, studies on the effect of pharmacist counselling followed by brief motivational reminders on the quality of life of diabetes mellitus patients is relatively scarce, particularly in Indonesia. The purpose of this study was to determine the effect of pharmacist counselling accompanied by brief motivational reminders on diabetic patients' quality of life and fasting blood sugar levels.

\section{METHODS}

\section{Research design and participants}

A pre-test-post-test quasi experimental design was employed in this study, where the participants were assigned into the intervention and control groups. The study was conducted at Jetis 1 primary health care in Bantul, Yogyakarta, Indonesia from May to August 2018. Research permit was obtained from the research site and the ethics committee. A total of 72 patients sought treatment for diabetes mellitus at Jetis 1 primary health care in Bantul, Yogyakarta. Patients who expressed an interest in participating in this study were asked to provide informed consent.

\section{Ethical clearance}

This study has been reviewed and obtained permission from the ethics committee of Universitas Ahmad Dahlan, Yogyakarta, Indonesia in 2018.

\section{Population and sample}

The population of this study consisted of patients with diabetes mellitus who sought treatment at the general polyclinic of Jetis 1 primary health care in Bantul, Yogyakarta. Random sampling was used, and the sample selected met the necessary criteria. The sample size was determined using the paired sample analysis formula. ${ }^{22}$ The Alpha standard deviation $(\mathrm{Z} \alpha)$ was 1.96 and the Beta standard deviation $(Z \beta)$ was 0.84 . The standard deviation was 3.62 and the minimum difference in the mean score (X1-X2) which was considered significant was 3.12. The standard deviation value and the minimum mean difference were determined by prior study. ${ }^{23}$ The minimum sample based on the calculation was 32 participants for each group (control and intervention).

\section{Inclusion, exclusion and lost follow up criteria}

The inclusion criteria of the research participants consisted of outpatients aged more than 18 years who were diagnosed as having type 2 diabetes with or without complications, receiving at least one oral antidiabetic drug for the last 3 months, having mobile phone communication media and being able to use it well (reading and replying to messages) and willing to participate in the study. Pregnant women and patients with hearing loss were excluded from this study. The criteria for lost follow-up participants were that the patients did not follow the study until it was completed and the patients withdrew during the study.

\section{Research instruments}

Data collection was carried out using informed consent, demographic data collection sheets (age, gender, occupation and comorbid); questionnaire; and medical records (fasting blood sugar level). The quality of life of the patients was measured using the SF-36 questionnaire which has been tested for validation and reliability in patients with diabetes mellitus. ${ }^{24}$ The SF-36 questionnaire is an instrument that can be used to measure the quality of life of patients with diabetes mellitus. This questionnaire measures the physical and mental health aspects of the patients. $^{25}$ The SF-36 questionnaire consists of the domains of physical function, emotional function, social function, emotional state, physical condition, pain, vitality and general health. The total score of SF 36's quality of life ranges from $0-100$ where a score of $\geq 80$ indicates a good quality of life and a score of $<80$ indicates a poor quality of life. The value of quality of life obtained from the total domain score compared to the number of domains. ${ }^{5}$

The SF-36 questionnaire used in this study has been proven to be valid and reliable. Based on research by Rachmawati et al validation and reliability tests were carried out with 30 patients. Convergent validity test showed a Pearson correlation coefficient $\geq 0.4$ on all question items, indicating that the instrument is valid. The 
reliability test showed a Cronbach's alpha value of $>0.7$ in all domains, indicating the reliability of each domain. ${ }^{26}$

The module used in Pharmacist Counselling has been validated by experts and posters related to the treatment of diabetes mellitus were adapted from the Ministry of Health of the Republic of Indonesia.

\section{Data collection}

Respondents who met the inclusion criteria were required to sign an informed consent form. The respondents were then separated into two groups: one for control and one for intervention. Following their physical examinations and prescriptions, respondents were questioned and surveyed using the SF-36 questionnaire as a pre-test. The respondents' fasting blood sugar levels were gathered from their medical records. The control group received usual care from the Primary Health Care institution, while the intervention group received counselling accompanied by brief reminders and motivational messages. Counselling was conducted utilizing medication posters to aid in the dissemination of information. Pharmacist counselling was provided by qualified counsellors and was based on the pharmacy brief counselling module. This counseling session lasted around 30 minutes. Following pharmacist counseling, the patients received brief reminders and motivational messages for one month (pause of patient visits to the primary health care institution). After one month, both groups were given the SF-36 questionnaire to assess their quality of life. The patients' fasting blood sugar levels were gathered from their medical records. Finally, the data were recapitulated and examined.

\section{Brief reminders and motivating messages}

Brief reminders and motivational messages in this study refer to research conducted by Adikusuma et al and Muthoharoh. ${ }^{21,27}$ Short messages that were sent to patients had been reviewed by experts. Each morning or afternoon, these messages were sent to remind and urge patients to continue with their treatment. In Indonesian, there are three distinct sorts of short messages. The first kind comprises brief reminders and motivations to take medication; the second type contains brief religious reminders and motivations; and the third type contains brief reminder messages to the doctor to maintain control. For around 30 days, brief messages were sent to the patients. During the first two weeks, brief messages were sent daily; after that, they were sent every three days. A total of 18 patients received the motivating messages via WhatsApp (WA), while 16 patients received the messages via a short message service (SMS).

\section{Data analysis}

The data were then analyzed using the t-dependent test to determine the difference in the mean scores of the patients' quality of life before and after the research intervention.
The Wilcoxon test was used to compare the mean fasting blood sugar levels of the patients before and after the intervention. Statistical package for social sciences (SPSS) version 20 was used for analysis. The difference was considered statistically significant if $\mathrm{p}<0.05$.

\section{RESULTS}

The total number of respondents who met the study's inclusion criteria was 72. Respondents were randomly assigned to one of two groups: the intervention group (36 respondents) or the control group (36 respondents). A total of 34 respondents from the intervention group finished the study, while two respondents were lost to follow-up due to their refusal to participate in the study until it was completed.

Table 1: Characteristics of respondents.

\begin{tabular}{|llll|}
\hline \multirow{2}{*}{ Karakteristik } & \multicolumn{1}{c}{$\begin{array}{l}\text { Control } \\
\text { group } \\
\text { Age }\end{array}$} & $\begin{array}{l}\text { Intervention } \\
\text { group }(\%)\end{array}$ \\
\hline & $\begin{array}{l}<60 \text { years } \\
\text { old }\end{array}$ & $\begin{array}{l}29 \\
(59.2)\end{array}$ & $20(40.8)$ \\
& old years & $7(30.4)$ & $16(69.6)$ \\
\hline \multirow{2}{*}{ Education } & $\leq 9$ years & $\begin{array}{l}16 \\
(37.2)\end{array}$ & $27(62.8)$ \\
\cline { 2 - 4 } & $>9$ years & $\begin{array}{l}20 \\
(69.0)\end{array}$ & $9(31.0)$ \\
\hline Comorbid & Hypertension & $\begin{array}{l}20 \\
(46.5)\end{array}$ & $23(53.5)$ \\
\cline { 2 - 4 } conditions & Dyslipidemia & $8(66.7)$ & $4(33.3)$ \\
\hline \multirow{2}{*}{$\begin{array}{l}\text { Present } \\
\text { medication }\end{array}$} & Metformin & $\begin{array}{l}35 \\
(50.7)\end{array}$ & $34(49.3)$ \\
\cline { 2 - 4 } & Glimepirid & $\begin{array}{l}20 \\
(57.1)\end{array}$ & $15(42.9)$ \\
\hline Duration & $\leq 4$ years & $\begin{array}{l}20 \\
(57.1)\end{array}$ & $15(42.9)$ \\
\hline $\begin{array}{l}\text { of } \\
\text { treatment }\end{array}$ & $>4$ years & $\begin{array}{l}16 \\
(43.2)\end{array}$ & $21(56.8)$ \\
\hline
\end{tabular}

More than half $(59.2 \%)$ of patients in the control group were under the age of 60 , while $69.6 \%$ of patients in the intervention group were above the age of 60 . According to educational attainment, $69 \%$ of patients in the control group had completed at least nine years of schooling, whereas $62.8 \%$ of patients in the intervention group had completed fewer than nine years of education (elementary and junior high school). Both research groups showed a high prevalence of concomitant hypertension. The patients were both prescribed metformin and glimepiride as oral antidiabetic medications. The findings of this study corroborate prior studies., ${ }^{8,28}$ Table 1 details the characteristics of the patients involved in this investigation.

In the pre-test, the blood sugar levels for the control group and intervention group were $192.84 \pm 75 \mathrm{mg} / \mathrm{dL}$ and 
$188.41 \pm 65.57 \mathrm{mg} / \mathrm{dL}$, respectively. Both groups thus showed high blood sugar levels, which exceed the blood sugar level threshold $(126 \mathrm{mg} / \mathrm{dL}) .{ }^{29}$ In the post-test, the control group reported higher blood sugar levels
(204.78 $\pm 90.46 \mathrm{mg} / \mathrm{dL})$ compared to the intervention group $(153.56 \pm 49.58 \mathrm{mg} / \mathrm{dL})$. The patients' blood sugar levels in the pre- and post-tests can be seen in Table 2 .

Table 2: Patients' fasting blood sugar levels in the Pre-test and Post-test (mean score \pm standard deviation).

\begin{tabular}{|lllll|} 
Group & Pretest $(\mathrm{mg} / \mathrm{dL})$ & $\begin{array}{l}\text { Post test } \\
(\mathrm{mg} / \mathrm{dL})\end{array}$ & $\Delta$ mean post test - pre-test & P value \\
\hline Control & $192.84 \pm 75$ & $204.78 \pm 90.46$ & $11,93 \pm 71.94$ & 0.330 \\
\hline Intervention & $188.41 \pm 65.57$ & $153.56 \pm 49.58$ & $-39,78 \pm 75.01$ & $0.007 *$ \\
\hline
\end{tabular}

P value from Uji Wilcoxon, (*) significant difference ( $\mathrm{p}<0.05)$. Symbol (-) in $\Delta$ mean post test - pre-test shows an increase in the patients' fasting blood sugar level

Table 3: Patients' quality of life in the pretest and post-test (mean score \pm standard deviation).

\begin{tabular}{|lllll} 
Group & Pre-test & Post test & $\Delta$ mean post-test - pre-test & P value \\
\hline Control & $73.99 \pm 12.51$ & $73.17 \pm 12.86$ & $-0.82 \pm 11.85$ & 0.677 \\
\hline Intervention & $74.22 \pm 10.53$ & $88.97 \pm 5.17$ & $13.73 \pm 9.22$ & $0.001 *$ \\
\hline
\end{tabular}

$\mathrm{P}$ value from $\mathrm{t}$-dependent test, $(*)$ significant difference $(\mathrm{p}<0.05)$. Symbol (-) in $\Delta$ mean post test - pre-test shows a decrease in quality of life

Table 4: The control group's scores in quality-of-life domains (mean score \pm standard deviation).

\begin{tabular}{|lllll|}
\hline Quality of life domains & Pretest & Post test & $\begin{array}{l}\Delta \text { mean post test }- \\
\text { pre test }\end{array}$ & P value \\
\hline General health & $55.45 \pm 14.01$ & $59.86 \pm 11.79$ & $4.4 \pm 14,63$ & 0.079 \\
\hline Physical function & $78.89 \pm 20.57$ & $82.36 \pm 18.34$ & $3.47 \pm 19,30$ & 0.288 \\
\hline Physical state & $62.50 \pm 36.10$ & $61.11 \pm 38.01$ & $-1.39 \pm 40,06$ & 0.836 \\
\hline Emotional state & $83.36 \pm 31.38$ & $80.56 \pm 33.25$ & $-2.81 \pm 26,84$ & 0.535 \\
\hline Social function & $95.47 \pm 11.35$ & $88.22 \pm 15.02$ & $-7.25 \pm 14,88$ & $0.006 *$ \\
\hline Body pain & $68.1 \pm 27.44$ & $60.11 \pm 31.44$ & $-7.99 \pm 35,19$ & 0.182 \\
\hline Vitality & $62.92 \pm 16.44$ & $71.81 \pm 11.54$ & $8.89 \pm 15,08$ & $0.001 *$ \\
\hline Mental health & $85 \pm 14.26$ & $81.11 \pm 15.93$ & $-3.89 \pm 17,25$ & 0.185 \\
\hline
\end{tabular}

$\mathrm{P}$ value from $\mathrm{t}$-dependent test, $(*)$ significant difference $(\mathrm{p}<0.05)$

Table 5: The intervention group's scores in quality-of-life domains (mean score \pm standard deviation).

\begin{tabular}{|lllll|}
\hline Quality of life domains & Pre-test & Post-test & $\begin{array}{l}\Delta \text { mean post test }- \\
\text { pre-test }\end{array}$ & $\begin{array}{l}\text { p-value } \\
\text { General health }\end{array}$ \\
\hline Physical function & $55.83 \pm 9.99$ & $74.44 \pm 9.18$ & $18.14 \pm 13.67$ & $0.001^{*}$ \\
\hline Physical state & $89.44 \pm 11.64$ & $98.53 \pm 3.15$ & $8.82 \pm 10.74$ & $0.001^{*}$ \\
\hline Emotional state & $61.11 \pm 34.56$ & $94.85 \pm 11.96$ & $33.09 \pm 37.29$ & $0.001^{*}$ \\
\hline Social function & $88 \pm 26.59$ & $97.09 \pm 9.50$ & $7.85 \pm 24.71$ & 0.073 \\
\hline Body pain & $93.81 \pm 10.56$ & $94.82 \pm 11.65$ & $0.88 \pm 12.75$ & 0.968 \\
\hline Vitality & $65.36 \pm 26.19$ & $85 \pm 17.65$ & $18.38 \pm 24.82$ & $0.001^{*}$ \\
\hline Mental health & $58.33 \pm 13.04$ & $75.29 \pm 9.69$ & $15.58 \pm 12.77$ & $0.001^{*}$ \\
\hline
\end{tabular}

$\mathrm{P}$ value from $\mathrm{t}-$ dependent test, $(*)$ significant difference $(\mathrm{p}<0.05)$

Based on the Wilcoxon test, there was a significant difference in fasting blood sugar values between the pretest and post-test in the intervention group. The patients' fasting blood sugar levels decreased significantly by $39.78 \pm 75.01 \mathrm{mg} / \mathrm{dL}$ after receiving pharmacist counselling accompanied by motivational reminder messages. However, there was no significant difference in blood sugar levels of patients in the control group before (pretest) and after (post-test) receiving the treatment (usual care from the health care institution).
The patients' quality of life scores can be seen in table 3 . Pre-test quality of life scores in the control and intervention groups were $73.99 \pm 12.51$ and $74.22 \pm 10.53$, respectively. This finding showed that both groups had a poor quality of life (quality of life score <80) on the pretest. The post-test quality of life scores reported by the control group ranged from $73.17 \pm 12.86$, while the posttest quality of life score observed in the intervention group was $88.97 \pm 5.17$. 
The results of the t-dependent test showed a significant difference in the quality-of-life scores between the pre-test and post-test of the intervention group. The significant difference indicated a change in the quality-of-life score, where the patients experienced an increase of $13.73 \pm 9.22$ in life quality scores. Meanwhile, there was no significant difference in the pre- and post-test scores on quality of life reported by the control group.

Quality of life consists of 8 domains. Therefore, further analysis was carried out to determine the relationship between brief counselling accompanied by short messages of reminders and motivation with the domain of quality of life. The domains of quality of life of patients in the control and intervention groups are presented in Table 4, 5.

The t-dependent analysis revealed a statistically significant difference in the mean score for the quality-of-life domain between pre- and post-test. Six quality of life domains showed a significant difference, which was showed by an increase in the patients' scores. The six domains are general health, physical, physical state, body pain, vitality, and mental health. However, two domains, namely emotional state, and social function, were not significantly different. Emotional state and social function experienced an increase after the intervention, but not statistically significant.

\section{DISCUSSION}

This study used the $5 \mathrm{~A}$ brief counselling method, which has the benefit of being time efficient and practical due to the presence of patient assessment. ${ }^{14}$ Patients in this study were counselled using poster media to aid in their comprehension of the information presented. The information sent to the patient was contingent upon the patient's state being assessed. Brief counselling and motivational reminder messages were given to the intervention group. The patients received brief messages reminding them to take their medication and motivating them to do so.

In this study, there was a significant decrease in the patients' fasting blood sugar levels following pharmacist counselling coupled by brief motivational messages. Numerous studies conducted in India demonstrated that when patients with diabetes mellitus received pharmacist advice, their fasting blood sugar levels decreased significantly. ${ }^{12,28,30}$ In Indonesia, research revealed a reduction in diabetic patients' fasting blood sugar levels by $14.66 \pm 43.19 \mathrm{mg} / \mathrm{dl}$ after receiving brief reminder messages. ${ }^{20}$ Another study in Indonesia showed a significant decrease in random blood sugar levels in patients after receiving pharmacist counselling accompanied by a short motivating messages. ${ }^{18}$

Counselling provided by pharmacists to diabetic patients includes education about the diseases they are diagnosed with as well as lifestyle adjustments. Thus, patients are anticipated to gain a better grasp of the ailment from which they are suffering. This understanding can aid in blood sugar control and the prevention of diabetes complications. ${ }^{18,23,30}$ Educating diabetic patients is a critical component of diabetes management. Diabetes education can aid in the treatment and control of blood sugar levels in patients with diabetes mellitus. ${ }^{31,32}$ Pharmacists in this study provided interventions in the form of short message services that reminded the patients to take oral anti-diabetic medications on a consistent basis. By doing so, it is expected that the patients' blood sugar levels were within control. ${ }^{20}$

Additionally, the effect of brief pharmacist counselling with motivational reminder messages on patient' quality of life was investigated in this study. The findings of this study revealed that when patients with diabetes mellitus received pharmacist counselling accompanied by brief reminder motivating messages, their quality of life improved dramatically. Similar findings were reported by researchers from India and Indonesia, namely that patients' quality of life improved significantly following pharmacist counselling. ${ }^{12,13,33}$ Another study conducted in Indonesia discovered that when diabetic patients received short message services as a reminder and motivation, their quality-of-life scores increased by $2.19 \pm 163.66 .{ }^{34}$

According to Shareef et al pharmacist involvement is critical for patients with diabetes mellitus to achieve better blood sugar management and a higher quality of life. Pharmacist interventions such as counselling regarding medications, diseases, and lifestyle modifications can help patients achieve treatment goals. Patients can avoid issues and improve their quality of life when their blood sugar is under control. ${ }^{12}$ Short messages can be used to communicate health messages to mobile phone owners, hence improving their medication adherence. ${ }^{34}$

Stanetic et al discovered that diabetes patients' quality of life improved significantly when their blood sugar was controlled. ${ }^{35}$ Quality of life is one of the main goals in treatment, especially for patients with diabetes mellitus. When blood sugar levels are effectively regulated, physical symptoms caused by acute or chronic difficulties can be avoided. ${ }^{36}$ This is consistent with the findings of Shareef et al, who discovered that greater blood sugar control in patients with diabetes mellitus was associated with fewer physical symptoms, improved mood, and wellbeing, all of which led in a higher quality of life and health. ${ }^{12}$

Diabetes mellitus is associated with physical and psychological problems that might have a negative impact on one's quality of life. Several studies have shown that the quality of life of patients with diabetes mellitus has low scores in the domains of physical, social function, body pain, physical condition, emotional state, mental health and general health. ${ }^{4-6}$

The results of this study showed that following the intervention, there was an increase in the patients' quality 
of life scores in the domains of general health, physical health, physical condition, bodily pain, vitality, and mental health. Muthoharoh discovered that when patients with diabetes mellitus received brief counselling and motivating messages, their quality of life scores in the domains of physical function and physical condition improved greatly. ${ }^{27}$ Another study found that providing brief counselling to patients with hypertension, combined with brief reminder messages and motivation, can significantly improve the patients' scores in practically all aspects of quality of life. ${ }^{15}$ These findings suggest that pharmacist intervention in the form of counselling coupled with brief reminders and motivational messages can help patients with chronic conditions such as diabetes or hypertension improve their quality of life.

In this study, the patients' emotional state and social function improved slightly but not dramatically. The intervention may need to be administered for an extended period of time and continually. Al Mazroui et al demonstrated that ongoing counselling can improve patients' quality of life across all domains. ${ }^{10} \mathrm{We}$ acknowledge the study's limitations, including the fact that not all patients in Jetis 1 primary health care in Bantul, Yogyakarta own a cell phone. Clearly, this particular constraint affected the study's small sample size.

\section{CONCLUSION}

Pharmacist counselling and brief reminder motivating messages can significantly decrease diabetic patients' blood sugar levels by $39.78 \pm 75.01 \mathrm{mg} / \mathrm{dL}$ and improve the patients' quality of life by $13.73 \pm 9.22$. The provision of pharmacist counselling supplemented by brief reminders and motivational messages might be viewed as an effort to optimize diabetic mellitus patient management.

\section{ACKNOWLEDGMENTS}

We wish to express our gratitude to the personnel and respondents at the Jetis 1 Public Health Center in Bantul, Yogyakarta, where the study was conducted. We would like to appreciate the assistance and support of the Dean and Lecturers at the Department of Pharmacy, Faculty of Mathematics and Natural Sciences, Universitas Lambung Mangkurat.

Funding: No funding sources Conflict of interest: None declared

Ethical approval: The study was approved by the Institutional Ethics Committee

\section{REFERENCES}

1. International Diabetes Federation. IDF Diabetes Atlas 9th Edition. International Diabetes Federation. 2019.

2. WHO. Diabetes. World Health Organization. Published 2020. Available at: https://www.who.int/ news-room/fact-sheets/detail/diabetes. Accessed on 1 September, 2020.
3. American Diabetes Association. Diabetes Care in the Hospital: Standards of Medical Care in Diabetes2021. Diabetes Care. 2021;44(1):S211-S20.

4. Sarac SF, Tutuncuo P, Parildar S, Saygili F, Candeger Y, Tüzün M. Quality of Life in Turkish Diabetic Patients. Turk Jem. 2007;11:48-53.

5. Teli M. Kualitas Hidup Pasien Diabetes Melitus Tipe 2 Di Puskesmas Se Kota Kupang. Jurnal Info Kesehatan. 2017;15(1):119-34.

6. Trikkalinou A, Papazafiropoulou AK, Melidonis A. Type 2 diabetes and quality of life. World J Diabetes. 2017;8(4):120-9.

7. Ojieabu WA, Bello SI, Arute JE. Evaluation of pharmacists' educational and counselling impact on patients' clinical outcomes in a diabetic setting. Journal of Diabetology. 2017;8(1):7-11.

8. Saputri GZ, Akrom, Dania H, Sari OM. Validation of Diabetes Mellitus Patient Behavior Questionnaire in Primary Health Care Service. IJPHS. 2019;8(4):45560.

9. Adepu R, Rasheed A, Nagavi BG. Effect of patient counseling on quality of life in type-2 diabetes mellitus patients in two selected South Indian community pharmacies: A study. Indian Journal of Pharmaceutical Sciences. 2007;69(4):519.

10. Al Mazroui NR, Kamal MM, Ghabash NM, Yacout TA, Kole PL, McElnay JC. Influence of pharmaceutical care on health outcomes in patients with Type 2 diabetes mellitus. British Journal of Clinical Pharmacology. 2009;67(5):547-57.

11. Chow EP, Hassali MA, Saleem F, Aljadhey H. Effects Of Pharmacist-led Patient Education On DiabetesRelated Knowledge And Medication Adherence: A Home-Based Study. Health Education Journal. 2016;75(4):1-13.

12. Shareef J, Fernandes J, Samaga L. Impact of pharmacist's intervention on improving quality of life in patients with diabetes mellitus. Journal of Diabetes, Metabolic Disorders \& Control. 2016;3(4).

13. Syarifuddin S, Nasution A, Dalimunthe A, Khairunnisa. Impact of Pharmacist Intervention on Improving the Quality of Life of Patients with Type 2 Diabetes Mellitus. Open Access Maced J Med Sci. 2019;7(8):1401-5.

14. Vallis M, Piccinini-Vallis H, Sharma AM, Freedhoff Y. Clinical review: modified 5 As: minimal intervention for obesity counseling in primary care. Can Fam Physician. 2013;59(1):27-31.

15. Ariyani H. Multi Profesional Kolaboratif Untuk Meningkatkan Kualitas Hidup Penderita Hipertensi Di Banjarmasin, Kalimantan Selatan, Indonesia. Prosiding Rakernas dan Pertemuan Ilmiah Tahunan Ikatan Apoteker Indonesia. 2016;103-10.

16. Mulianti R. Pengaruh Brief Counseling dan Short Message Service (SMS) Terhadap Tingkat Perilaku Adhrensi, Kepatuhan Minum Obat dan Hasil Terapi Pasien Diabetes Mellitus Dengan Hipertensi Rawat Jalan Poliklinik Penyakit Dalam RSUD Panembahan Senopati Bantul Yogyakarta. Published online. 2014. 
17. Nurwijayanti A. Brief Counseling and Mobile Phone Short Message Service (SMS) Increase Patient Compliance. International Journal of Pharma Medicine and Biological Sciences. 2015;4(3):175-9.

18. Saputri GZ, Akrom, Muhlis M, Muthoharoh A. Efek Konseling Menggunakan Brief Counseling 5A Modifikasi Disertai Pesan Motivasional Farmasis dalam Peningkatan Perilaku dan Outcome Klinik Pasien Diabetes Melitus dengan Hipertensi Rawat Jalan di RSUD Panembahan Senopati, Bantul. IJCP. 2019;8(1).

19. Thakkar J, Kurup R, Laba TL. Mobile Telephone Text Messaging for Medication Adherence in Chronic Disease: A Meta-analysis. JAMA Intern Med. 2016;176(3):340-9.

20. Alfian R. Layanan Pesan Singkat Pengingat untuk Meningkatkan Kepatuhan Minum Obat dan Kontrol Glikemik Pasien Diabetes Melitus di RSUD Dr. H. Moch. Ansari Saleh Banjarmasin. Media Farmasi: Jurnal Ilmu Farmasi. 2015;12(1):129-38.

21. Adikusuma W, Qiyaam N. Adherence Level And Blood Sugar Control Of Type 2 Diabetes Mellitus Patients Who Gets Counseling And Short Messages Service As Reminder And Motivation. Asian J Pharm Clin Res. 2018;11(2):219.

22. Dahlan S. Besar Sampel Dalam Penelitian Kedokteran Dan Kesehatan. 3rd ed. Salemba Medika. 2013.

23. Malathy R, Narmadha MP, Jose AM, Ramesh S, Babu DN. Effect of a Diabetes Counseling Programme on Knowledge, Attitude and Practice among Diabetic Patients in Erode District of South India. Journal of Young Pharmacists. 2011;3(1):65-72.

24. Rafi'ah N, Perwitasari DA, Sh JDS, Korespondensi P. The Association Between Illness Perception With Quality Of Life In Type 2 Diabetes Mellitus Patient With Complications In Abdul Wahab Sjahranie Hospital Samarinda. 2012;16.

25. Gusmai L de F, Novato T de S, Nogueira L de S. The influence of quality of life in treatment adherence of diabetic patients: a systematic review. Rev esc enferm USP. 2015;49(5):839-46.

26. Rachmawati Y, Perwitasari DA, Adnan A. Validasi Kuesioner SF-36 Versi Indonesia Terhadap Pasien Hipertensi Di Puskesmas Yogyakarta. Pharmacy: Jurnal Farmasi Indonesia (Pharmaceutical Journal of Indonesia). 2014;11(1).

27. Muthoharoh A. Pengaruh Brief Counseling 5A Dan Pesan Motivatif Dalam Meningkatkan Kualitas Hidup Pasien Diabetes Melitus Dengan Hipertensi Rawat Jalan Poliklinik Penyakit Dalam Di RSUD Panembahan Senopati Bantul. Published online. 2017.
28. Renuga E, Ramakrishnan S, Rani V, Thennarasu P, Kannan G. Impact Of Continuous Patient Counselling On Knowledge, Attitude, And Practices And Medication Adherence Of Diabetic Patients Attending Outpatient Pharmacy Services. Asian Journal of Pharmaceutical and Clinical Research. 2016;9(1):3649.

29. ADA. Diabetes Care-Standards of Medical Care in Diabetes. J Clin and App Res Edc: Diabetes Care. 2020;43(1):16.

30. Swaroop AM, Varghese C, Jose J. Patient Counseling On Knowledge, Attitude, Practice and Medication Adherence Type 2 Diabetes Mellitus Patients. European Journal of Pharmaceutical and Medical Research. 2016;3(4):231-5.

31. Solanki JD, Sheth NS, Shah CJ, Mehta HB. Knowledge, attitude, and practice of urban Gujarati type 2 diabetics: Prevalence and impact on disease control. Journal of Education and Health Promotion. 2017;6(1):35.

32. Kakade AA, Mohanty IR, Rai S. Assessment of knowledge, attitude and self-care activities among type-2 diabetic patients attending a tertiary care teaching hospital. International Journal of Basic \& Clinical Pharmacology. 2016;5(6):2458-62.

33. Septiar HE, Utami P. Pengaruh Konseling Farmasis Terhadap Kualitas Hidup Dan Kadar Gula Darah Pada Pasien Diabetes Mellitus Tipe 2 Di Puskesmas Gedong Tengen Periode Maret-Mei 2014. Jurnal Farmasi Sains dan Praktis. 2015;1(1):29-34.

34. Nopitasari BL, Adikusuma W, Asamuni GRD. Pengaruh Pemberian Layanan Pesan Singkat Sebagai Pengingat Dan Motivasi Terhadap Kualitas Hidup Pasien Diabetes Melitus Tipe 2 Dengan Terapi Antidiabetik Oral. Jurnal Ilmiah Ibnu Sina. 2018;3(1):179-85.

35. Stanetic K, Savic C, Racic M. The Quality Of Life Of Patients With Type 2 Diabetes Mellitus. Opsta Medicina. 2012;18(3-4):70-7.

36. Laoh JM, Tampongangoy D. Gambaran Kualitas Hidup Pasien Diabetes Mellitus Di Poliklinik Endokrin RSUP Prof. Dr. R. D. Kandou Manado. Jurnal Ilmiah Perawat Manado (Juiperdo). 2015;4(1):32-7.

Cite this article as: Sari OM, Saputri GZ, Akrom. Diabetes mellitus patients' fasting blood sugar levels and quality of life following brief pharmacist counseling with reminders and motivational messages. Int J Basic Clin Pharmacol 2022;11:13-9. 